\title{
The Potentiality of Municipal Solid Waste to Produce Volatile Fatty Acids
}

\section{(VFAs)}

\author{
M. S. A. Amin *, M. M. Alam, M. S. I. Mozumder \\ Department of Chemical Engineering and Polymer Science, Shahjalal University of Science \& \\ Technology, Sylhet 3114, Bangladesh
}

Received 5 October 2018, accepted in final revised form 18 November 2018

\begin{abstract}
Volatile fatty acids (VFAs) are proposed platform molecules for the production of basic chemicals and polymers from organic waste streams. A simple bio-reactor was fabricated with locally available materials to conduct this study. A lab-scale anaerobic batch reactor was fed with potato waste and banana waste as substrate to find out the potential organic waste that has maximum VFAs production capacity. Between these two wastes, banana waste was found better for VFAs production. The product spectrum remained similar at the $\mathrm{pH}$ range 4.0-4.5 but higher $\mathrm{pH}$ reduced the VFAs production. The operation of anaerobic digestion with uncontrolled $\mathrm{pH}$ reduced the $\mathrm{pH} 4.0$ to 4.5 . Therefore, it is better to run the anaerobic digestion without controlling the $\mathrm{pH}$ while aiming to VFAs production. A small amount nutrient (ammonium nitrogen) significantly increases the VFAs production but higher amount nutrient has an inhibition effect. However commercial surfactant has a strong inhibition effect on VFAs producing organism and hence reduced the VFAs production. The efficient production of VFA at uncontrolled $\mathrm{pH}$ with a small amount of ammonium nitrogen increases the economic feasibility of organic waste-based VFAs production.
\end{abstract}

Keywords: Anaerobic digestion; Bioconversion; Volatile fatty acids; Municipal solid waste.

(C) 2019 JSR Publications. ISSN: 2070-0237 (Print); 2070-0245 (Online). All rights reserved. doi: http://dx.doi.org/10.3329/jsr.v11i1.38457 J. Sci. Res. 11 (1), 133-143 (2019)

\section{Introduction}

One of the biggest challenges in human development in the 21 st century is ensuring the effective food waste management. The impact of food waste on the environment is unavoidable [1-3]. The amount of food waste is increasing extremely in every year around the world [4,5]. Therefore, it becoming the major source of environmental decay, odor, toxic gas production, and groundwater contamination, which severely threatens environmental health and security [6]. Some existing methods for disposal of food waste such as landfill, ocean dumping, incineration, animal feed and fertilizers have been

*Corresponding author: $\underline{\text { msaamin-cep@ sust.edu }}$ 
forbidden somewhere or some other places it become less desirable [7,8]. As a result, an efficient, sustainable and eco-friendly treatment and/or management of food waste is required to overcome this problem. Resource recovery from waste could be considered one of the best alternatives by to generate the clean energy and valuable chemicals. This type of bio-based process is rapidly gaining importance in our society, veering towards oil replacement with renewable and sustainable sources of carbon and energy. Now-a-days the demand for renewable chemicals and fuels are pushing the industry towards higher sustainability, to improve cost effectiveness and meet customers' demands with sustainability $[9,10]$.

Compared to other wastes, food waste contains higher levels of organic materials, such as starches, proteins and lipids [11]. It could be a plentiful source of inexpensive organic substrate to generate energy and other products due to its highly organic composition, well balanced carbon and nutrient content and easy biodegradation [12]. Anaerobic digestion is preferred as an efficient pathway for their cycling and reduction of food waste and involve the conversion of complex organic through a multistep process involving the production of soluble compounds, short-chain fatty acids and hydrogen [13]. The process of anaerobic digestion consists of four steps: hydrolysis, acidogenesis, acetogenesis, and methanogenesis [14]. Volatile fatty acids are produced in the first three steps by eliminating the methane-forming phase $[15,16]$. Acidogenesis of food waste can also produce valuable products such as $\mathrm{H}_{2}$, which is a clean fuel [17-19].

VFAs are important bulk chemicals that are used as building blocks to produce polymers, as acidulants, preservatives and favoring agents, or as precursors for the synthesis of chemicals. Based on previous studies, VFAs have been successfully used for nutrient removal enhancement [20], biodegradable plastic production [21] biogas and biodiesel bioconversion [22], polyhydroxyalkanoate biosynthesis [23] and electricity generation [24]. Additionally, Srikanth et al. [25] demonstrated that VFAs are a potential substrate for hydrogen production via photo fermentation by mixed microbial cultures. Nowadays VFAs are usually derived from fossil fuels through chemical synthesis [26]. The production of VFAs from municipal waste will become one of the most attractive, economic and sustainable way to meet the future demand of renewable chemicals and fuels. These can be possible to achieve through finding an efficient and cheap substrate and/or an effective design and optimization of the fermentation process, for which it is necessary to have insight into the micro- and macro-mechanisms of the process. Short chain carboxylic (volatile fatty) acids (VFAs) production in mixed microbiomes is majorly limited by the prevalence of methanogenic bacteria and the availability of substrate from waste to the biocatalyst during the fermentation process. To enhance the VFAs production from waste, the present study evaluates a strategy for selective enrichment of the biocatalyst by selecting specific waste and exposing it to controlled $\mathrm{pH}$, temperature etc. The enhancing VFAs production will help to sustainable chemical and bio-fuel production in one way and the other way it will helpful for waste management as well as reduce the greenhouse gas emission. 
The aim of this study is to increase VFAs production through anaerobic digestion using potato and/or banana waste as substrate. Dilution has a significant effect on this process but still mechanism is unknown, would be investigated here. Moreover, the effect of nutrient such as $\left(\mathrm{NH}_{4}\right)_{2} \mathrm{SO}_{4}$, and inhibitor (detergent) were evaluated in view of VFAs production.

\section{Materials and Methods}

\subsection{Source of food waste}

The food wastes used in this study were collected from the cafeteria, tea stall and the student dormitory of Shahjalal University of Science \& Technology (SUST), Sylhet. The food waste contains mainly potato, banana, gourd etc.

\subsection{Waste processing}

In order to optimize the VFAs production or to get high performance of VFA production process, food waste processing is important. At first the bones, metals, chopsticks, plastic bags and inorganic residuals were removed from the collected waste materials and the desired organic wastes were stored. Among various food wastes, potato waste and banana waste were separated from the stored mixed organ waste. Then both potato and banana wastes cut into small size to increase the production potential.

\subsection{Anaerobic digester}

The anaerobic digester was made using a $2 \mathrm{~L}$ plastic bottle. The reactor was facilitated with sample collection system. To collect and measure the gas sample $250 \mathrm{~mL}$ measuring cylinder was connected with the reactor. There was water in measuring cylinder and it was measured through the metering system under normal temperature and pressure conditions. The temperature was maintained in mesophilic condition. Before any operation with the digester, a leakage test of the reactor was carried out to ensure that no oxygen could get into the reactor.

\subsection{Experimental procedure}

The potentiality of two food wastes; potato waste and banana waste were evaluated to find out the potential waste substrate aiming to produce maximum VFAs production. $400 \mathrm{~g}$ waste was added with $5 \mathrm{~g}$ of digested sludge in $250 \mathrm{~mL}$ solution in a $2 \mathrm{~L}$ anaerobic digestor. The sludge was produced in laboratory in an already existing anaerobic digester. Digested sludge used to stimulate microbial growth as well the digestion. The details condition to evaluate the potentiality of potato and banana waste on VFAs production are listed in Table 1. 
Table 1. Details condition to evaluate the effect of dilution.

\begin{tabular}{lccc}
\hline Types of waste & $\begin{array}{c}\text { Added volume of water } \\
(\mathrm{mL})\end{array}$ & $\begin{array}{c}\text { Amount of waste } \\
(\mathrm{g})\end{array}$ & $\begin{array}{c}\text { Amount of digested sludge } \\
(\mathrm{g})\end{array}$ \\
\hline $\begin{array}{l}\text { Potato } \\
\text { Banana }\end{array}$ & 250 & 400 & 5 \\
\hline
\end{tabular}

$\mathrm{pH}$ played a vital role for the production of VFAs with simultaneous suppression of methane formation. The $\mathrm{pH}$ was varied from 4.0 to 5.5 to find out the optimal $\mathrm{pH}$ for maximum VFAs production. In this study banana waste was used as substrate and other condition was as like as the Table 1.

Ammonium-nitrogen $\left(\mathrm{NH}_{4}{ }^{+}\right)$played a significant role in microbial growth as it is an essential nutrient for growth. Moreover, Huang et al. [27] found significant increase of VFAs production but for the commercial surfactant (detergent), it was not clear. The commercial detergent was collected from the local market. To investigate the effect of $\left(\mathrm{NH}_{4}\right)_{2} \mathrm{SO}_{4}$ and detergent on VFAs production, banana waste was used with $5 \mathrm{~g}$ sludge in $250 \mathrm{~mL}$ of water. The detailed experimental conditions are summarized in Table 2.

Table 2. The detailed experimental conditions for investigating the effect of $\left(\mathrm{NH}_{4}\right)_{2} \mathrm{SO}_{4}$ and detergent.

\begin{tabular}{|c|c|c|c|c|}
\hline \multirow{2}{*}{$\begin{array}{l}\text { Types of } \\
\text { waste }\end{array}$} & \multirow{2}{*}{$\begin{array}{l}\text { Added volume } \\
\text { of water, (mL) }\end{array}$} & \multirow{2}{*}{$\begin{array}{l}\text { Amount of } \\
\text { waste, }(\mathrm{g})\end{array}$} & \multirow{2}{*}{$\begin{array}{l}\text { Amount of digested } \\
\text { sludge, }(\mathrm{g})\end{array}$} & Amount of chemical dosages \\
\hline & & & & $\left(\mathrm{NH}_{4}\right)_{2} \mathrm{SO}_{4},(\mathrm{~g})$ \\
\hline Banana & 250 & 400 & 5 & $\begin{array}{ll}0.5 & 1.0\end{array}$ \\
\hline Banana & 250 & 400 & 5 & without addition of chemical \\
\hline
\end{tabular}

\subsection{Volatile Fatty Acid (VFA) determination methods}

Volatile fatty acids are the acids with carbon chain of six carbons or fewer. In this study, it was measured as acetic acid equivalent based on the measurement of $\mathrm{pH}$ and dissociated acetic acid $\left(\mathrm{C}_{\mathrm{DA}}\right)$. The concentration of dissociated acetic acid $\left(\mathrm{C}_{\mathrm{DA}}\right)$ can be determined from the $\mathrm{pH}$ and $\mathrm{pKa}$. $\mathrm{pH}$ was determine using $\mathrm{pH}$ electrode. The basic principle of VFA determination are as follow:

$$
\begin{aligned}
& \mathrm{CH}_{3} \mathrm{COOH} \leftrightarrow \mathrm{CH}_{3} \mathrm{COO}^{-}+\mathrm{H}^{+} \\
& \mathrm{C}_{\mathrm{A}}=\mathrm{C}_{\mathrm{DA}}\left(10^{\mathrm{pH}-\mathrm{pKa}}+1\right) / 10^{\mathrm{pH}-\mathrm{pKa}}
\end{aligned}
$$

Here, $\mathrm{C}_{\mathrm{A}}$ is the concentration of VFA as acetic acid (mmol/L); $\mathrm{C}_{\mathrm{DA}}$ is dissociated acetic acid $\mathrm{H}^{+}$concentration (mmol/L). pKa values are 4.75 for acetic acid; 4.88 for propionate and 4.82 for butyrate respectively.

Moreover, all the VFAs measurement except 'the evaluation of effect of $\mathrm{pH}$ on VFAs production was evaluated through the $5 \mathrm{pH}$ point titration VFAs measurement method developed by Vannecke et al. [28]. All the measurements were within $\pm 5 \%$. 


\section{Results and Discussion}

\subsection{Comparison of substrate}

Two food waste; potato waste and banana waste were evaluated to find out its potentiality for the VFAs production. The experiment was carried out with $400 \mathrm{~g}$ waste within $250 \mathrm{~mL}$ solution in a $2 \mathrm{~L}$ anaerobic digestor. In this case no nutrients were added and $\mathrm{pH}$ was not controlled. The overall results are shown in Fig. 1(a,b). The higher VFAs production 156 $\mathrm{mmol} / \mathrm{L}(9.12 \mathrm{~g} / \mathrm{L})$ acetic acid equavalant was found from banana waste compare to potato which produced amount $82.5 \mathrm{mmol} / \mathrm{L}(4.95 \mathrm{~g} / \mathrm{L})$ acetic acid equivalent VFAs. A comparison study on VFAs production from different feedstock have summarized in Table 3. Micolucci et al. [29], and Giuliano et al. [30], found higher VFAs production compare to this study using food waste as feedstock and this was due to applying higher temperature. They used $55{ }^{\circ} \mathrm{C}$ temperature while in this study the temperature was uncontrolled and never was higher than $42{ }^{\circ} \mathrm{C}$.

The $\mathrm{pH}$ of the uncontrolled reactor dropped to 4.4 for the potato waste and to 4.0 for the banana waste (Fig. 1b). Jiang et al. [12] also found a quick drop of $\mathrm{pH}$ to about 3.0 due to the production and accumulation of VFAs and similar trend was also reported previously by Kim et al. [31] and Dogan et al. [15].

Several studies have already conducted to apply the banana and potato waste as substrate for the production of production of VFAs and methane through anaerobic digestion. Banana starches which are relatively low in amylase content, have high resistance to heating and amylase attack, low swelling properties, low solubility in water and low retrogradation, been proved slightly superior to other starch [32]. Emaga et al. [33] have successfully isolated and characterized pectins $(87-248 \mathrm{kDa})$ from the banana peels bearing variable compositions of neutral sugars (galactose, arabinose and rhamnose), galacturonic acid and different degrees of esterification. It contains considerable amount of starch, sugars, and higher minerals specially potassium compares [34]. One of the main reasons for higher production of VFAs as well as higher rate of VFAs production with banana waste was the high content of minerals. It gave the advantages to acetogenasis better activities through ATP production.

Table 3. VFAs production capacity from different feedstock.

\begin{tabular}{llll}
\hline Feedstock & $\begin{array}{l}\text { Yield } \\
\text { gVFA/kgCOD }\end{array}$ & $\begin{array}{l}\text { Concentration } \\
\text { VFAs, g/L }\end{array}$ & References \\
\hline Organic fraction of municipal solid waste & $31-263$ & $2.5-19.6$ & {$[35,36]$} \\
Food Waste & $221-234$ & $12.3-13.7$ & {$[29,30]$} \\
Food Waste and Rice Straw & - & $5.5-25.0$ & {$[37]$} \\
Fruit/Vegetable waste & $33-279$ & $7.6-28.5$ & {$[38]$} \\
Waste activated sludge & 383 & 11.4 & {$[39]$} \\
Corn straw & - & 6.77 & {$[40]$} \\
Caw Manure-maize silage & $62-183$ & $6.7-14.6$ & {$[41]$} \\
Banana waste & - & 9.12 & In this study \\
Potato waste & - & 4.95 & In this study \\
\hline
\end{tabular}



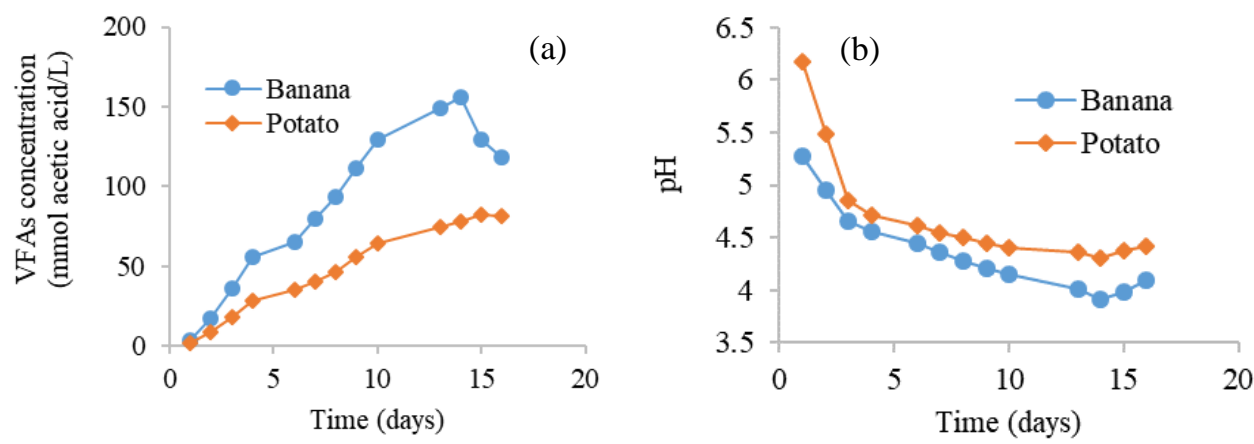

Fig. 1. Comparison of the potentiality of banana waste and potato waste for VFAs production (a) VFAs concentration and (b) uncontrolled $\mathrm{pH}$ response.

\subsection{Effect of $p H$}

Four reactors were operated for 16 days with controlled $\mathrm{pH} 4.0,4.5,5.0$, and 5.5 respectively and were maintained throughout the experiment through online $\mathrm{pH}$ control. In the first step of anaerobic digestion, insoluble organic polymers such as carbohydrates, proteins, and fats are broken into simple sugars, fatty acids, and amino acids. The solubilization of the solid organic fraction of food waste can cause increase in soluble COD in the reactor [12]. In this study, the conversion of insoluble organic substrate to soluble COD increased gradually with decreasing $\mathrm{pH}$ (Fig. 2). The maximum VFAs concentrations were observed at $\mathrm{pH} 4.5$ which was in agreement with the reports of Tamis et al. [42].

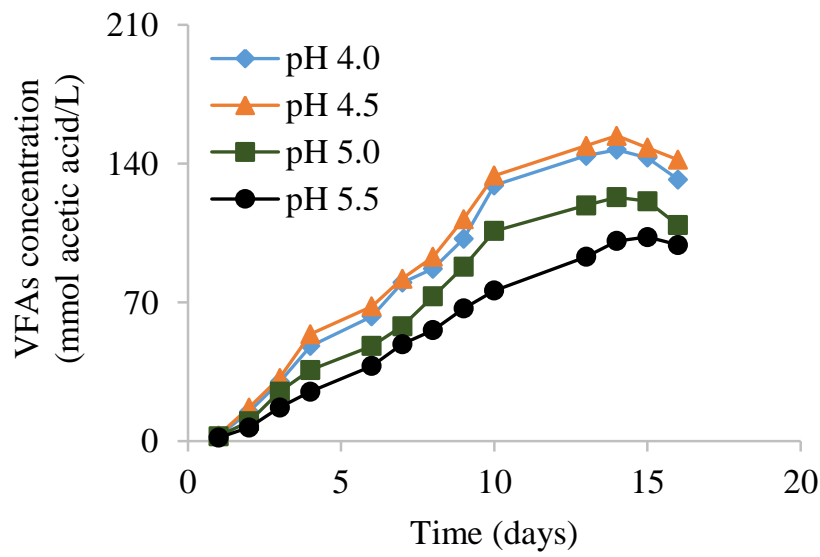

Fig. 2. Effect of $\mathrm{pH}$ for the VFAs production from banana waste.

VFAs were produced in the acidogenesis and acetogenesis steps. Fig. 2 shows the variation in VFAs concentration in the reactor at different $\mathrm{pH}$ conditions. Under all $\mathrm{pH}$ conditions, the concentration increased rapidly at first 10 days and then was relatively slow and then decreased due to enhance the bio-gas production from VFAs. The 
maximum VFAs concentrations at $\mathrm{pH}$ 4.0, 4.5, 5.0 and 5.5 were 147, 154, 123 and 103 $\mathrm{mmol} / \mathrm{L}$, respectively at the days around 14-15. The highest VFAs production was occurred at $\mathrm{pH}$ 4.5. The VFAs concentration was very close to the maximum value when $\mathrm{pH}$ was uncontrolled. This is because $\mathrm{pH}$ dectreased to 4.5 to 4.0 while it was uncontrolled shown in Fig. 1(b) and also supported by literatures [15,31].

\subsection{Effect of $\left(\mathrm{NH}_{4}\right)_{2} \mathrm{SO}_{4}$ addition}

The effect of ammonium-N concentration was evaluated using $2 \mathrm{~g} / \mathrm{L}$ and $4 \mathrm{~g} / \mathrm{L}$ initial $\left(\mathrm{NH}_{4}\right)_{2} \mathrm{SO}_{4}$ concentration with $400 \mathrm{~g}$ banana waste in $250 \mathrm{~mL}$ solution. The process was run at an uncontrolled $\mathrm{pH}$. The overall results comparing with no addition of $\left(\mathrm{NH}_{4}\right)_{2} \mathrm{SO}_{4}$ are summarized in Fig. 3(a, b). Increasing the ammonium-N concentration stimulate the VFAs production and a maximum $205.5 \mathrm{mmol} / \mathrm{L}$ acetic acid equivalent VFAs were produced while initial $2 \mathrm{~g} / \mathrm{L}\left(\mathrm{NH}_{4}\right)_{2} \mathrm{SO}_{4}$ was used. Further increasing the ammonium-N concentration decreased the VFAs concentration (Fig. 3a).

Ammonium- $\mathrm{N}$ is known as an essential nutrient for biomass growth, therefore presence of ammonium-N enhanced the growth and productivity of VFAs production. However, VFAs production became low at $4 \mathrm{~g} / \mathrm{L}\left(\mathrm{NH}_{4}\right)_{2} \mathrm{SO}_{4}$ and this was due to its inhibition effect to VFAs producing organism.

The gas production was comparatively higher while no $\left(\mathrm{NH}_{4}\right)_{2} \mathrm{SO}_{4}$ was used (Fig. 3b). Adding ammonium- $\mathrm{N}$ decreased the gas production but changing the ammonium-N concentration do not have the significant effect on gas production. It indicates that the ammonium- $\mathrm{N}$ have the significant effect on acetogenesis but not on methanogenesis bacteria.

In anaerobic fermentation where food waste or municipal solid waste were used as substrate, ammonia was produced by the biological degradation of nitrogenous compounds, mostly in the form of protein, which was hydrolyzed into amino acids and further degraded into ammonia [43]. In a study with food waste, the ammonia concentration was found relatively stable, and was maintained at between 600 and 700 $\mathrm{mg} / \mathrm{L}$ which is equivalent to 2.2 to $2.5 \mathrm{~g} / \mathrm{L}\left(\mathrm{NH}_{4}\right)_{2} \mathrm{SO}_{4}$ with an uncontrolled $\mathrm{pH}$ system [12]. Therefore, while the mixed food waste was used, the ammonium-N concentration level was almost at its optimal level about to $2 \mathrm{~g} / \mathrm{L}\left(\mathrm{NH}_{4}\right)_{2} \mathrm{SO}_{4}$ and the optimal ammonium-N concentration also confirmed in this study as about $600 \mathrm{mg} / \mathrm{L}$.

\subsection{Effect of commercial detergent on VFAs production}

Variations of VFAs production from banana waste in presence of commercial surfactant are shown in Fig. 4(a). The blank test approached (without commercial surfactant) its maximum VFAs concentration of $154 \mathrm{mmol} / \mathrm{L}$ acetic acid equivalent at day 15. Addition of commercial surfactants sharply reduced the VFAs production and it's approached to zero while surfactant concentration was $1.6 \mathrm{~g} / \mathrm{L}$. 

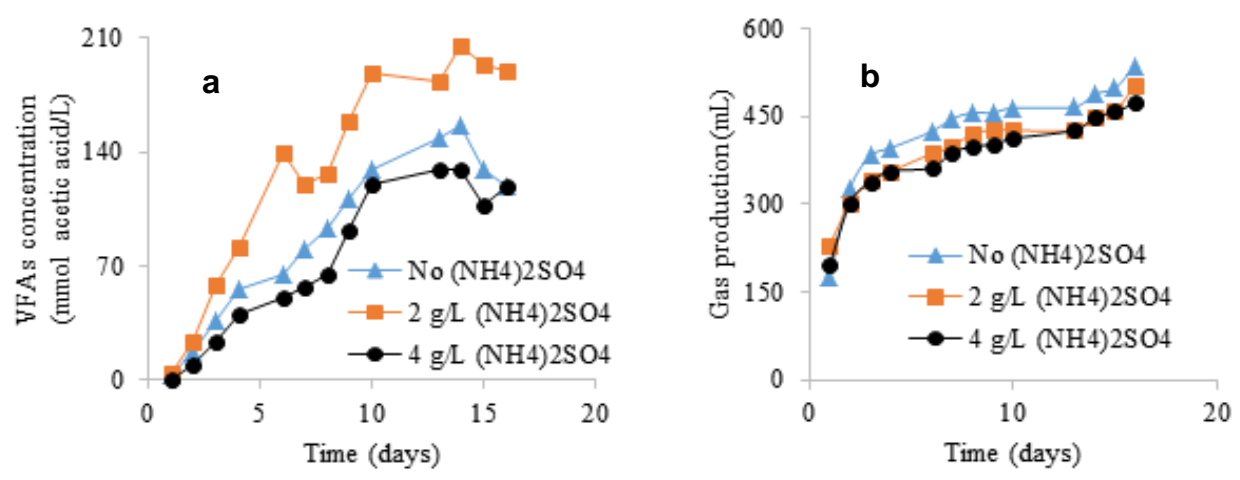

Fig. 3. Effect of ammonium-N concentration on an anaerobic digester; (a) VFAs production and (b) gas production.

Huang et al. [27] found significant increase of VFAs accumulation using biosurfactants during anaerobic fermentation with uncontrolled $\mathrm{pH}$. High surface activity of the bio-surfactant was the fundamental reason to the enhancement of organic matters solubilization hydrolysis, which was beneficial to VFAs production. Bio-surfactants can inhibit the methanogenesis during anaerobic digestion which also help to increase the VFAs production and reduce the bio-gas production [27]. But for the commercial surfactants the opposite phenomenon was observed in this study. The bio-gas production increased with increasing commercial surfactant concentration in the anaerobic digester. Without addition of commercial surfactant, the maximum bio-gas production was $536 \mathrm{~mL}$ after 17 days. However, the gas production was increased to $1081 \mathrm{~mL}$ by adding $0.8 \mathrm{~g} / \mathrm{L}$ surfactant and to $1476 \mathrm{~mL}$ by adding $1.6 \mathrm{~g} / \mathrm{L}$ surfactant (Fig. 4b).
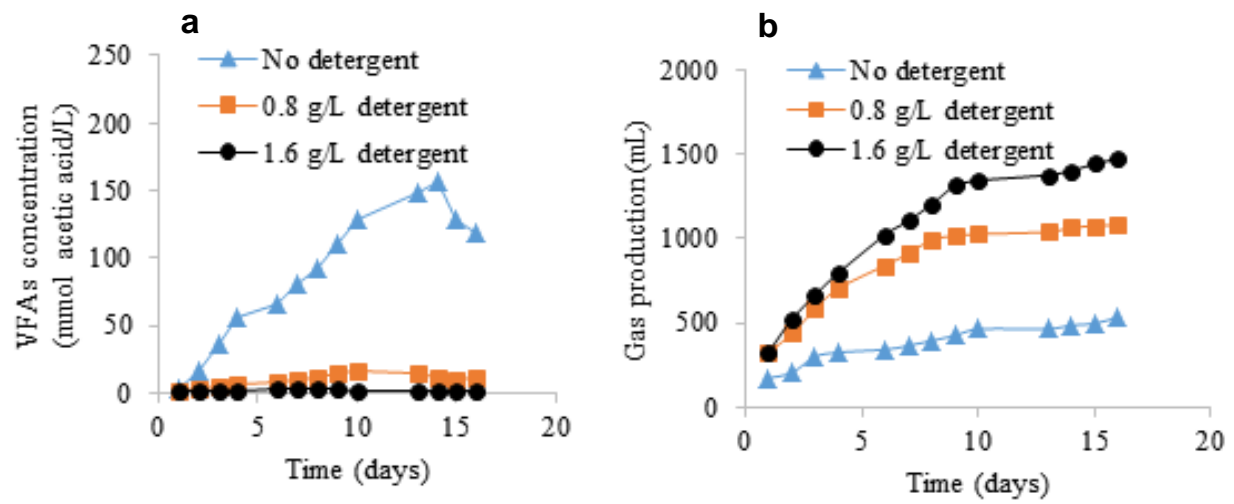

Fig. 4. Effect of commercial detergent on an anaerobic digester; (a) VFAs production and (b) gas production.

Most commercially available surfactants, synthesized from petroleum by-products may has strong inhibition effect on acidogenic bacteria but do not inhibit methanogenic bacteria. High VFAs concentration has an inhibition effect on methanogenic bacteria [44]. 
The presence of commercial detergent limited the VFAs production; VFAs production was the rate limiting step and reduced the VFAs accumulation and increased the bio-gas production.

\section{Conclusions}

Between two most abundant food waste; potato waste and banana waste, the letter one was found better in view of VFAs production. $\mathrm{pH}$ has a significant effect on VFAs production, increased with decreasing $\mathrm{pH}$. However, the product remained almost same at the $\mathrm{pH}$ range 4.0-4.5. The operation of anaerobic digestion with uncontrolled $\mathrm{pH}$ reduced the $\mathrm{pH}$ to between 4.0 and 4.5. Therefore, it is better to run the anaerobic digestion without controlling the $\mathrm{pH}$ while aiming to VFAs production. A small amount ammonium nitrogen (nutrient) significantly increased the VFAs production while high amount nutrient significantly decreased the VFAs production due to its inhibition effect. The commercial surfactant showed an inhibition on VFAs producing organism and hence reduced the VFAs accumulation. The efficient production of VFAs at uncontrolled $\mathrm{pH}$ with a small amount of ammonium nitrogen increases the economic feasibility of wastebased VFAs production.

\section{References}

1. B. Grizzetti, U. Pretato, L. Lassaletta, G. Billen, and J. Garnier, Environ. Sci. Policy 33, 186 (2013). https://doi.org/10.1016/j.envsci.2013.05.013

2. A. Periathamby, Municipal Waste Management, in Waste (Academic Press, Boston, 2011) pp.109-125. https://doi.org/10.1016/B978-0-12-381475-3.10008-7

3. Eurostat, Municipal Waste Statistics (2016).

4. W. Concern, Bangladesh Waste Database 2014 (2014).

5. FAO, Global Food Losses and Food Waste (2011).

6. W. Guo, Q. Wu, S. Yang, H. Luo, S. Peng, and N. Ren, RSC Adv. 4, 53321 (2014). https://doi.org/10.1039/C4RA08202H

7. A. D. Cuéllar and M. E. Webber, Environ. Sci. Technol. 44, 6464 (2010). https://doi.org/10.1021/es100310d

8. K. Komemoto, Y. G. Lim, N. Nagao, Y. Onoue, C. Niwa, and T. Toda, Waste Management 29, 2950 (2009). https://doi.org/10.1016/j.wasman.2009.07.011

9. A. Corma, S. Iborra, and A. Velty, Chem. Rev. 107, 2411 (2007). https://doi.org/10.1021/cr050989d

10. A. Corma, S. Iborra, and A. Velty, Chem. Rev. 107, 2411 (2007). https://doi.org/10.1021/cr050989d

11. H. Moon, I. S. Song, J. C. Kim, Y. Shirai, D. H. Lee, J. K. Kim, S. O. Chung, D. H. Kim, K. K. Oh, and Y. S. Cho, Int. J. Energy Res. 33, 164 (2009). https://doi.org/10.1002/er.1432

12. J. Jiang, Y. Zhang, K. Li, Q. Wang, C. Gong, and M. Li, Bioresour. Technol. 143, 525 (2013). https://doi.org/10.1016/j.biortech.2013.06.025

13. D. Batstone, J. Keller, I. Angelidaki, S. Kalyuzhnyi, S. G Pavlostathis, A. Rozzi, W. T. M. Sanders, H. Siegrist, and V. Vavilin, Water Sci. Technol. 45, 65 (2002).

14. M. A. D. L. Rubia, F. Raposo, B. Rincón, and R. Borja, Bioresour. Technol. 100, 4133 (2009). https://doi.org/10.1016/j.biortech.2009.04.001

15. E. Dogan, T. Dunaev, T. H. Erguder, and G.N. Demirer, Chemosphere 74, 797 (2009). https://doi.org/10.1016/j.chemosphere.2008.10.028 
16. M. Gryta and M. Barancewicz, Polish J. Chem. Technol. 13, 56 (2011).

17. D. H. Kim, S. H. Kim, K. W. Jung, M. -S. Kim, and H. S. Shin, Bioresour. Technol. 102, 8646 (2011). https://doi.org/10.1016/j.biortech.2011.03.030

18. D. Y. Lee, Y. Ebie, K. Q. Xu, Y. Y. Li, and Y. Inamori, Bioresour. Technol. 101, S42 (2010). https://doi.org/10.1016/j.biortech.2009.03.037

19. M. Li, Y. Zhao, Q. Guo, X. Qian, and D. Niu, Renewable Energy 33, 2573 (2008). https://doi.org/10.1016/j.renene.2008.02.018

20. P. Fontanille, V. Kumar, G. Christophe, R. Nouaille, and C. Larroche, Bioresour. Technol. 114, 443 (2012). https://doi.org/10.1016/j.biortech.2012.02.091

21. Y. Jiang, Y. Chen, and X. Zheng, Environ. Sci. Technol. 43, 7734 (2009). https://doi.org/10.1021/es9014458

22. H. N. Chang, N. J. Kim, J. Kang, and C. M. Jeong, Biotech. Bioproc. Eng. 15, 1 (2010). https://doi.org/10.1007/s12257-009-3070-8

23. H. Chen, H. Meng, Z. Nie, and M. Zhang, Bioresour. Technol. 128, 533 (2013). https://doi.org/10.1016/j.biortech.2012.10.121

24. Y. Chen, J. Luo, Y. Yan, and L. Feng, Appl. Energy 102, 1197 (2013). https://doi.org/10.1016/j.apenergy.2012.06.056

25. S. Srikanth, S. V. Mohan, M. P. Devi, D. Peri, and P. N. Sarma, Int. J. Hydrogen Energy 34, 7513 (2009). https://doi.org/10.1016/j.ijhydene.2009.05.095

26. T. Eggeman and D. Verser, Appl. Biochem. Biotechnol. 122, 605 (2005). https://doi.org/10.1385/ABAB:122:1-3:0605

27. X. Huang, C. Shen, J. Liu, and L. Lu, Chem. Eng. J. 264, 280 (2015). https://doi.org/10.1016/j.cej.2014.11.078

28. T. P. W. Vannecke, D. R. A. Lampens, G. A. Ekama, and E. I. P. Volcke, Environ. Technol. 36, 861 (2015). https://doi.org/10.1080/09593330.2014.964334

29. F. Micolucci, M. Gottardo, D. Bolzonella and P. Pavan, Int. J. Hydrogen Energy, 39, 17563 (2014). https://doi.org/10.1016/j.ijhydene.2014.08.136

30. A. Giuliano, L. Zanetti, F. Micolucci, and C. Cavinato, Water Sci. Technol. 69, 2200 (2014). https://doi.org/10.2166/wst.2014.137

31. M. Kim, C. Y. Gomec, Y. Ahn, and R. E. Speece, Environ. Technol. 24, 1183 (2003). https://doi.org/10.1080/09593330309385659

32. P. Zhang, R. L. Whistler, J. N. BeMiller, and B. R. Hamaker, Carbohydrate Polym. 59, 443 (2005). https://doi.org/10.1016/j.carbpol.2004.10.014

33. T. H. Emaga, C. Robert, S. N. Ronkart, B. Wathelet, and M. Paquot, Bioresour. Technol. 99, 4346 (2008). https://doi.org/10.1016/j.biortech.2007.08.030

34. D. Mohapatra, S. Mishra and N. Sutar, J. Sci. Ind. Res. 69, 323 (2010).

35. C. Cavinato, A. Giuliano, D. Bolzonella, P. Pavan, and F. Cecchi, Int. J. Hydrogen Energy 37, 11549 (2012). https://doi.org/10.1016/j.ijhydene.2012.03.065

36. G. Chinellato, C. Cavinato, D. Bolzonella, S. Heaven, and C.J. Banks, Int. J. Hydrogen Energy 38, 4351 (2013). https://doi.org/10.1016/j.ijhydene.2013.01.078

37. X. Chen, H. Yuan, D. Zou, Y. Liu, B. Zhu, A. Chufo, M. Jaffar, and X. Li, Chem. Eng. J. 273, 254 (2015). https://doi.org/10.1016/j.cej.2015.03.067

38. P. Traverso, P. Pavan, D. Bolzonella, L. Innocenti, F. Cecchi, and J. Mata-Alvarez, Biodegradation 11, 407 (2000). https://doi.org/10.1023/A:1011687230823

39. W. R. M. Leite, M. Gottardo, P. Pavan, P. B. Filho and D. Bolzonella, Renewable Energy 86, 1324 (2016). https://doi.org/10.1016/j.renene.2015.09.069

40. D. Li, C. Jiao, W. He, Z. Yan, Y. Yuan, Z. Li, Y. Guo, and X. Liu, Int. J. Hydrogen Energy 41, 5456 (2016). https://doi.org/10.1016/j.ijhydene.2016.01.141

41. C. Cavinato, C. D. Ros, P. Pavan, and D. Bolzonella, Bioresour. Technol. 223, 59 (2017). https://doi.org/10.1016/j.biortech.2016.10.041

42. J. Tamis, B. M. Joosse, M. C. M. V. Loosdrecht, and R. Kleerebezem, Biotechnol. Bioeng. 112, 2248 (2015). https://doi.org/10.1002/bit.25640 
43. D. Jun, Z. Yong-sheng, H. Mei, and Z. Wei-hong, J. Hazard. Mater. 163, 717 (2009). https://doi.org/10.1016/j.jhazmat.2008.07.066

44. Y. Wang, Y. Zhang, J. Wang, and L. Meng, Biomass Bioenergy 33, 848 (2009). https://doi.org/10.1016/j.biombioe.2009.01.007 